\title{
Stuart Hall as a criminological theorist-activist
}

\begin{abstract}
What is the legacy of Stuart Hall for and to criminology, beyond just Policing the Crisis? In this article I highlight two other engagements in race and policing that Hall was part of, one in the 1980s through an independent inquiry, the other in the 1990s through a major public inquiry. Beyond bringing to light this work, this article shows how these engagements reveal Hall's unique style of theorising the concrete politics of the present through his stress upon conjunctures and context, and via the concept of articulation. Hall's interventions in these two cases underscore an analytical and theoretical stance in public forums that make him more than a 'scholar-activist' but rather a 'theorist-activist' who drew on theory for strategic and 'applied' purposes. The ways in which he did this can, I suggest, point to different ways of 'doing race' in a critical criminology.
\end{abstract}

Keywords: Racism, policing, politics, public engagement, public criminology 
Since his death in 2014 there have been a large number of tributes and publications attesting to the influence of Stuart Hall, who retired as a Professor of Sociology at the Open University in 1997. A recurring theme in those is Hall's role as a public intellectual through his many projects and activities in the arts and to an extent in public policy, with the Runnymede Trust for example. The accolades also point to his public pedagogy through his Open University teaching, as well as in a wide range of speaking and publishing engagements, including his contributions to Marxism Today in the 1980s, and to Soundings from the late 1990s to his demise, let alone his earlier work with the 'new left' in the 1960s. The range and depth of activity within and beyond the academy makes clear that Hall was always more than just an 'ivory tower' scholar; the impressive and extensive praise for his work underscores the value of his contributions over more than five decades. The question or issue here though is where does criminology feature in this? Or to put it another way, in what ways does Hall's other work, apart from the well known and probably now classic ${ }^{1}$ text Policing the Crisis (Hall et al 1978, revised edition 2013) speak to criminology? This question underlines this article's aim to both extend the scope of criminological understandings of Hall's work, as well as to challenge and unsettle his established place within academic studies of crime and policing. To do that entails looking beyond Hall et al (1978), his best-known contribution in criminology. It requires a way of trying to connect his public persona and actions with his 'criminological' imagination (I put this in quotes because I doubt that Hall ever thought of himself as a criminologist, and he was certainly not constrained by disciplinary boundaries) even if - or maybe precisely because - it is not recognised in criminology itself, even in generous appraisals of his work (Webster 2009).

While Hall's standing as a public intellectual is not in doubt, it is worth noting that this term or category is a loose and sometimes unhelpful one, especially when it implies or envisions a 'great man' of history, fearlessly - but also largely individually - speaking 'truth to power'. Hall did not decry the label of public intellectual but his commitment to collective work in so many instances made him anything but individualistic. In contrast to the idea of public intellectuals, others prefer the more democratic and 'bottom up' notion of 'scholar-activism' as a way of conceiving the role of scholars in the academy, and their engagements with social movements and politics (Murji and Bhattchyyrra 2014). My purpose here is to advance a claim that 
Hall was more than both of these things and I put forward the claim that Hall can usefully be thought of as a 'theorist-activist'. This is a term that could overlap with both public intellectual and scholar-activism but it carries a different inflection to both. It is not an expression that appears to have any currency but I have devised it not for the purpose of creating new categories for their own sake but rather to try to capture something distinctive about Hall, and in particular his relation to criminology in the public engagements to be discussed. While the term could also be applied to much or all of his other public endeavours, in the current context it intended to draw out the ways in which he drew on or 'operationalized' theory, or particular concepts in relation to race and policing. The purpose is to show not just what Hall did as a form of public criminology, but also how he did it. While there are several instances of such engagements in race and policing issues, here I examine only two cases. The first is Hall's involvement with an independent inquiry that was published in 1989 as a book, Policing in Hackney. The second is from 1998 when Hall and others prepared a report that fed into the Macpherson (1999) inquiry into the death of Stephen Lawrence.

Although all of Hall's 'public' interventions in the politics of crime and policing are centrally about race, his approach to that transcends race as it is often used in criminology. From the 1970s to the late 1990s Hall contributed to a number of inquiries and reports such as the deaths of the two young black men discussed in this article, as well as on riots or disorders in the inner cities in the 1980s, or the policing of a far-right demonstration in which an anti-racist protestor was killed, most likely by the actions of a police officer. While race and racism are the common thread across all of those, Hall of course wrote on more than that across his vast number of publications. What matters here though is how he conceived and positioned the connections around race, crime and policing by situating/re-situating, and dis- and rearticulating them. In this light, Hall's approach transcends the confines of criminology even while considering matters such as the rule of law and justice. A sense of what this entails is suggested when in discussing Policing the Crisis he said of it that:

If you'd just taken race as a black issue, you'd have seen the impact of law and order policies on the local communities, but you'd have never seen the degree to which the race and crime issue was a prism for a much larger social crisis. You wouldn't have looked at the larger picture. You'd have written a 
black text, but you wouldn't have written a cultural studies text because you wouldn't have seen this articulation up to the politicians, into the institutional judiciary, down to the popular mood of the people, into the politics, as well as into the community, into black poverty and into discrimination (Hall, cited in Grossberg 2006: 3)

In the 'larger picture' Hall makes of race and policing something more than 'just race' and law and order. His interventions show that he is always seeking to connect them to other things - law, history, society, class, nation, empire. Importantly though these are not 'bigger', but things that are essentially interconnected or bound up together they form the context in which race - and policing - are to be understood. Though I caution against taking any pat lessons from this, the value of Hall's approach is that it offers a different way of thinking about criminology's encounters with race, which remain problematic (Phillips and Webster 2013, Parmar 2017).

\section{Theory as a detour to somewhere 'more important'}

A seeming paradox of labelling Hall as a theorist-activist is that he said 'I don't regard myself as a theorist in the sense that that is my work'. While Hall is widely discussed as a cultural and social theorist it is more accurate to refer to his theorising, rather than a specific theory that he can be linked to. In the words that run on from the previous quote he added: 'I am interested always in going theorising about the world, about the concrete but...not in the production of theory in its own right. And therefore I use theory in strategic ways... because I think my object is to think the concreteness of the object in its many different relations' (Hall, interview with Scott, cited in Grossberg, 2007: 99). For critics, such as Rojek (2003), Hall was an intellectual butterfly switching from Althusserian to Gramscian Marxism and later into poststructuralism. Yet for many others (e.g. Procter 2004, Rustin 2007) it his intellectual signature to be a sort-of theoretical 'bricoleur' using theory strategically to excavate contemporary phenomena. Or, as Clarke puts it Hall was engaged in 'discovering necessary elements in many different places and seeing what might happen if they were put together to illuminate pressing analytical and political issues' (Clarke 2015: 282), 
The engagement with 'the concrete' points the way towards the activist engagements this article considers. For Rustin (2007) Hall's interest was less in particular events or in abstract theories than in finding ways of connecting them. At one level this is evident in what he actually did throughout his career such as Hall's contributions on race for UNESCO (Hall 1980a) and the $\mathrm{CRE}^{2}$ (Hall 1978); his analyses of Thatcherism (Hall 1988); his development of the idea of new ethnicities in the 1980s, plus his various essays on questions of the post-colonial and globalization (Hall 1991) in the 1990s, and on to his critiques of New Labour (Hall 1998), and of neo-liberalism (Hall et al 2015) in later decades. In all these cases Hall's acuity was focussed on theorising the present, or to put it another way, he was always concerned with specific moments which he seeks to make sense of by using and developing theory.

Hence, thinking 'the concrete' is not just an abstraction but a rather a modus operandi, a kind of deep-seated, even foundational stance towards engaging the present. This is a form of agile or strategic theorising - or what Procter (2004) refers to as theory as action or intervention, or Grossberg calls 'theorized empiricism'. It aims to retain the specificity and details of the concrete or empirical moment without making it just empiricist. It does this not just by intertwining the theoretical and the empirical, but also reading across and connecting the epistemological and the historical (Grossberg 2007). This is theory done not for its own sake, or in exchange with social theorists in an academic forum, but theory as a practice or an activity. It 'is a detour on the road to somewhere more important' (Hall, cited in Procter 2004: 54) that helps to 'ground our engagement with what newly confronts us and to let that engagement provide the ground for retheorizing' (Slack 1996: 114). It is a tool to make sense of specific moments, to place them in context analytically by understanding the ways in which cultures, ideologies, structures are drawn on, involved and combined in the concrete. Hall stated it in this form: 'I do think you have to analyse the things that are in front of you and try to understand how they really are and not how you would like them to be. And then try to find out what the possibilities are for change and work with those. Yes, that is my strategy' (cited in Alexander 2009: 462).

For current purposes I want to draw on two ideas or concepts that Hall utilised conjuncture/context, and articulation. On the former, in a discussion with Doreen 
Massey, Hall outlined 'two distinct conjunctures.... separated by the crisis of the 1970s...The period, dominated by the welfare state, public ownership and wealth redistribution through taxation was one conjuncture; the neoliberal, market-forces era unleashed by Thatcher and Reagan was another' (Hall and Massey 2010: 57). While this identifies a conjuncture as akin to an era, in the more refined sense that Hall uses it identifies the 'specific and distinctive shape' when different social, political, economic and ideological contradictions...come together'. In criminology, the fullest account of this is of course in Policing the Crisis. Hall sees that as one of the first texts in English to use conjunctural analysis, even though he notes that in it, 'almost casually, almost by chance, we hit on the moment of transition between two major conjunctures' (in Jhally 2016: 336). Hall et al (1978) analysed the moment of mugging in the generation of public consent through the media to the emergence of law and order society and authoritarian populism. Mugging, and law and order, condensed or symbolised the crisis, which is understood in the context of social anxiety about race and migration, combined with British economic and imperial decline and the changing role of the state. While Hall never called this a or the multicultural conjuncture, I contend that in Policing the Crisis and in his other writings on race and policing, he reads crises as centrally framed by and through race. As he noted himself, the 1978 book was 'one of the first moments in cultural studies when the question of race and culture really came to the centre.... [It] raise[s] the questions of the mugger to a more general level. It starts to say, this is about the crisis around the questions of race... it gives the centrality to racial distinctions, which are usually thought of as separate from class distinctions' (in Jhally 2016: 332, 335).

Among sympathetic readers of Hall there is a degree of disagreement about the relationship between conjuncture and context. For Grossberg conjunctural analysis is a critical practice that is about more than 'mere context' as he puts it. In this formulation a context seeks to understand an event as the product of histories that precede the event - it is 'the beginning and the end of our researches. The trajectory from the beginning to the end provides the measure of our success at mapping, at arriving at a better description/understanding of the context' (Grossberg 2006: 3). A conjuncture is a moment or a period where knowledge can be articulated in relation to political struggles (Grossberg 2007). This latter point in key because while Hall's public interventions are too short to develop conjunctural analysis, and could be seen 
as 'just' contextualising, their purpose in an applied or public arena is clearly to intervene in the politics of race and policing narrowly, as well as raising wider concerns about law and justice, and race and nation. Slack however makes a stronger case for contextualising in arguing that what a cultural study does is to 'map the context—not in the sense of situating a phenomenon in a context, but in... mapping the very identity that brings the context into focus (Slack 1996: 126, emphasis in original).

The other key theoretical resource is articulation. For Slack (1996) this is both a theory and a method in Hall's work; as a theory it seeks to avoid either reductionism and/or essentialism while as a method it suggests ways of contextualizing. Hall put it this way himself:

By the term 'articulation', I mean a connection or link which is not necessarily given in all cases, as a law or a fact of life, but which requires particular conditions of existence to appear at all, which has to be positively sustained by specific processes, which is not 'eternal' but has to be constantly renewed, which can under some circumstances disappear or be overthrown, leading to the old linkages being dissolved and new connections - re-articulations being forged (Hall, cited in Clarke 2015: 277)

Importantly, this speaks to the contingent nature of articulations in the ideological and cultural spheres - they require work to construct and to maintain; they are not given for all time, they are not 'guaranteed' to have effects and, in particular, they can be dis- and re-articulated (Clarke 2015). ${ }^{3}$

In his public interventions I maintain that Hall is concerned with a radical focus on contextualisation/re-contextualisation, combined with dis- and re-articulation. In his UNESCO essay Hall (1980a) used articulation in the dual sense of 'joining together' as well as 'giving expression to'. Without using words such as theory, or concepts like conjuncture and articulation, this is what he is 'operationalizing' through his public activities in race and policing. That is, he underscores how things are or can be 'joined together' in a different frame, in order to raise questions about the operation of state power and legitimacy, and of imperial and colonial histories, as well as how race 'gives expression' to those things. A crucial point is that the particular is not just framed within the general; rather the two are seen as intricately and necessarily 
linked. Extensions of this line of thinking are evident in various works such as Hillyard's (1985) analysis of the colonial roots of policing in Northern Ireland, Ryan's (2013) stress on 'pressure from below' through family campaigns for justice, or Scraton's (2016) account of the independent Hillsborough inquiry. These showcase a critical criminological perspective that seeks to bring the state and history back into an analysis of what might otherwise be treated as just particular cases.

\section{Reconfiguring race and policing}

Although Hall had multiple public engagements in race and policing cases, for present purposes I focus only on two of those. In one he is named as an adviser to a local inquiry on Policing in Hackney. This is the report of an Independent Committee of Inquiry (1989) established by the Roach Family Support Campaign (RFSC). The campaign followed from the death of Colin Roach, a 21-year-old black man, in Stoke Newington [North London] police station in January 1983.When in late 1983 an Inquest jury decided by a majority of 8-2 on a verdict of suicide, the RFSC appealed for a public inquiry. They also wrote to the Home Secretary criticising the way the police had treated Colin's parents, Mr and Mrs Roach whose complaint was referred to the Police Complaints Board, though in 1984 it decided that there would be no disciplinary action against any of the police officers involved. In 1985 the campaign group set up its independent inquiry, with the support of the local Labour council, Hackney, after repeated refusals by the Home Office for a public inquiry ${ }^{4}$. The format of the Independent Inquiry, which was launched in 1985, seems to have been modelled on $\mathrm{NCCL}^{5}$ type inquiries, entailing an expert and diverse panel taking evidence in an investigative manner to arrive at reasonable inferences and conclusions. Why Hall was an adviser to the inquiry, rather than a panellist, is not known, though it is possible his then recent or on-going work with another inquiry into the 1985 riots in Handsworth, Birmingham could have limited his time. Hall provides a foreword to the published report of the RFSC inquiry (Independent Committee of Inquiry 1989). As this one of the few instances in the range of public engagements he had where he is a sole author it provides a valuable insight into the way he articulated theory in a concrete or specific case. 
The second case is the much better known major public inquiry into the death of Stephen Lawrence. This took evidence in 1998 and produced a widely discussed report in 1999 (Macpherson 1999). Yet it is perhaps typical of Hall's public activities across decades that the document he co-wrote on is nowhere cited in Macpherson, is not listed among the evidence, and there is no copy of it in the official records of Macpherson in the UK National Archive. Hall came into this work through a commission by the lawyers for Duwayne Brooks (the friend of Stephen Lawrence who was with him on the night he was killed in South London in 1993), and they told me they invited Hall because, 'He may just be the best known person [on race]'. They felt they needed his expertise due to a concern that, 'It was clear the inquiry panel didn't have a grip on race. There wasn't a structure in place to explain this [how Duwayne was treated by the police] to the inquiry... to explain why the police had acted in a racist way towards Duwayne - so we decided that the way to do this was to gather expert evidence'. ${ }^{6}$ In 1998 Hall worked with two colleagues then at the Open University, Eugene McLaughlin and Gail Lewis, to produce a short report for the legal team for Brooks. While it was not officially evidence to Macpherson, it was important for the legal team who found it "very impactful...[it] gave us an enormous confidence because we were really small in this massive inquiry, while the main teams had lots of representation... [It had] a dual role - it gave us confidence and a steer'.7

Hall was called into both inquiries because of his renown as a pre-eminent public intellectual, such as his work on the BBC, and numerous public speaking roles, all of which seem to have been better known than his academic work, including Policing the Crisis. By the time of both inquiries he had already been active in public meetings on policing issues in Birmingham in the 1970s, while he was based at the University of Birmingham. He had also delivered a public lecture for the Cobden Trust in 1979 that was published as Drifting into a Law and Order Society (Hall 1980b), and served as a member of two independent inquires. However, even in Hall's voluminous writings all these activities are barely mentioned and went largely 'under the radar ${ }^{\circ}$. Thus it appears that Hall was asked to assist in Hackney and in Macpherson not because he was known as having given his time in other similar roles but mainly due to his public reputation as a critical thinker. 
Hall's public roles exemplify his desire to intervene in political issues and debates, rather than treat such matters at only a theoretical level. Intervention is a key word in this. In the introduction to Policing the Crisis the authors declare it to be an intervention in the battleground of ideas, and David Scott saw it as one of Hall's key contributions in commenting that Hall is 'less the author of books than the author of interventions' (cited in Alexander 2009: 459, emphasis in original). In mapping or understanding the context of race and policing in and since the 1970s Hall was intervening in a politically charged arena in academia as well beyond, as is evident in Gilroy (1987), for example. In the specific setting or context of London Hall was of course fully aware of the specific geographies as well as wider histories of race and place. In the 1970s and 1980s Hackney was one of the main areas regarded as a 'symbolic location' in London (Keith 1993). This term and such places were key sites that carried different meanings - as 'no go' areas for the police, or as places of black community life and counter-culture. The local police station in such areas, such as Stoke Newington in Hackney, attained a reputation of notoriety as locations where black people were framed by the police, or even died in custody. This is the context in which the death of Colin Roach is placed in Policing in Hackney. It is also part of the frame for the Macpherson (1999) report's finding of institutional racism in the police and the police's failures in case of racist murders such those of youngsters Rolan Adams in 1991 and Rohit Duggal in 1992 in South London, neither of which received any notable mainstream media coverage. ${ }^{9}$

While several witnesses, as well as Stephen's mother, mentioned the term stereotyping to Macpherson, the main echo between the Hall et al (1998) report and Macpherson is, unsurprisingly, in the chapter on Brooks. Hall et al combined a structural analysis with a psychosocial inflection to account for the persistent stereotyping of black men. Both elements reflect the interests of the three authors though it is clear that the former draws on Hall et al's (1978) analysis ${ }^{10}$, while the latter reflects some of Hall's other work at the time such as his contribution to Open University teaching on representation and stereotyping (Hall 1997). The 1998 report maintains that the stereotyping process was evidenced by police descriptions of Brooks as 'aggressive', 'intimidating' and 'excitable'. Hall et al (1998: 9) conclude that the police treated a distressed person as intimidating, a potential mugger or as 
unreliable and un-cooperative; all of these bear the hallmark of the racial stereotyping of a young black man, because he was part of a category who are 'never publicly conceptualised as victims of crime'. Macpherson (1999) reached a similar view in deciding that the police treated Brooks poorly as they saw him as a young black man involved in a gang fight rather than as a victim and a key witness. The police failed to see him as a traumatized victim, thus the inquiry was 'driven to the conclusion that Mr Brooks was stereotyped as a young black man exhibiting unpleasant hostility and agitation...(Macpherson 1999, para 5.12).

Hall et al (1998) did contextualise racial stereotyping in a policing context, but another source better fits the argument of this article about Hall's use of theory - an article he wrote around the same time for the History Workshop Journal (Hall 1999). Written more as historical contextualisation and to some extent a commentary, this does not necessarily use terms such as conjuncture or articulation but it reflects the deployment of theoretical tools that reveal the nature of his theorist-activist engagement. This is evident on the first page. While it is titled 'From Scarman to Stephen Lawrence', Hall (1999) begins by seemingly undermining or calling into question his own title. He proposes that the appropriate analytical periodisation of events is not, as the title indicates, from around 1980/1 to the late 1990s, or even from one public inquiry into race and policing to another. Rather he locates, or contextualises the murder of Stephen Lawrence and the Macpherson report in relation to the arrival of the SS Windrush in Tilbury in 1948 , the $50^{\text {th }}$ anniversary of which was celebrated in 1998 as the dawn of the supposedly multicultural era in Britain, with the arrival of West Indian migrants to the 'mother country'. In reconfiguring the perspective in this way Hall alters and re-articulates the context, making the case of Stephen Lawrence as something broader than just policing, or even race and policing, as it largely is in the Hall et al (1998) report.

In making this move Hall effectively recontextualises the case of Stephen Lawrence as part of a longue duree that reveals or exposes the relation of citizens to the state and in particular the ways in which supposedly equal (legal) citizens are treated, or regarded unequally by the state. The racist attack on Stephen Lawrence is one instance of the under-protection of black citizens. Significantly, writing many years before the Black Lives Matter campaign, Hall is already outlining a perspective on 
those lines by making both lateral and vertical connections to multiple black deaths across time and space in Britain. In locating the murder of Stephen Lawrence within a spate of deaths of black people- mostly men, often young - sometimes in connection with the police, sometimes in violent racist attacks - he stretches the temporal context beyond the two decades from Scarman to Macpherson, and the spatial context from South London to Great Britain. Cosequently, Hall's analysis is belied by the title he used. Instead he narrates a wider story of the limits of multiculturalism, and its difficulties - though in a manner quite different from the 'backlash' against diversity prominent since the $1980 \mathrm{~s}$ - to locate it as a failure on the part of the state to view and treat black people as equal citizens.

This is about more than the police, and relations between police and black communities, though that has continued to be 'a catalogue of disasters, marked by mistrust, prejudice and disrespect, often leading to tragedy' (Hall 1999: 188). Policing and the rule of law have what he calls a 'symptomatic value' about the relation of citizens to the state. In that vein it illuminates how racialised difference is 'being negotiated at a deeper level' (p.189) that challenges claims of Britain drifting into a tolerant multicultural society (recall this is the time of New Labour's celebration of a new inclusive Britain), a view that cannot hold because of severe, sometimes fatal, racialised effects of the logics of racism and exclusion. This includes policing but stretches beyond that when Hall presciently identifies a persistent and unresolved 'English nationalism that feels beleaguered and abandoned' (p.192). In this framing there is a gesture at the wider conjuncture that straddles and stretches beyond the two eras or periods of the post-war welfare state and the neo-liberalism of the 1980s that he identified in another context. Race, nation and empire are bound together in the British social fabric, and national psyche, in ways that systematically neglect the precarity of black lives and the experience of violent racism. Again, while Hall did not call this a multicultural conjuncture by centring race as the place or the moment where contradictions in law, history, nation and society are condensed, that is what I think he is pointing to.

One of the reasons for focusing on these two of Hall's engagements is to highlight a parallel between them that he made but did not labour in his subsequent writings, 
though it again reveals how perceptive his analyses look in retrospect. Various authors have argued that the reason that the case of Stephen Lawrence became the focus on a public inquiry is because the media and the police could not simply pigeonhole him within the gallery of racialised/criminalised black demonology, from mugging in the 1970s to yardies in the 1990s (Hall et al 1978, Gilroy 1987. Keith 1993). In Holohan's (2005) media analysis the ultimately different treatment of Stephen shows how some black people can be 'whitened' in media discourse if they can be fitted into tropes that separate them from the racialised stereotype of unruly and dangerous black men. Yet in his foreword Hall (1989) was already drawing attention to the differential value placed on black lives, such as that of Colin Roach. By suggesting that the official account is so 'fishy' as he calls it, he adds 'It is open to doubt, for example, whether any Home Secretary in his right mind would calmly and quietly acquiesce in such an implausible story as an adequate explanation of the death of his own son in similar circumstances' (Hall 1989: 12). In making Colin Roach into someone who could have been anyone's son Hall is clearly posing the question of whether law and justice do apply equally to black people. His comment anticipates the ways that the case of Stephen Lawrence was treated as 'different', because he was a young black man who could not be stereotyped - he wished to train as an architect and had a 'conventional' family background. Reinforced by the prominent campaign by the Daily Mail he could not just be reduced to a 'ragamuffin' (as Brooks seems to have been seen and treated). Thus it seems unlikely to be just a coincidence that Hall had already made just that point to the Macpherson inquiry (Hall et al 1998).

In the case of Colin Roach Hall did something different. He recontextualised it by simultaneously localising and nationalising it by setting the specific story of Hackney within the frame of black community experiences of policing, and of racism. He points to the short-term history of policing in Stoke Newington and the multiple complaints of over-policing of black people locally, and makes it an issue of trust and confidence of the local population in the police: 'The death of Colin Roach did not take place in a vacuum. It happened in a place, in a community, in a context which has its own history. This history is part and parcel of 'the Colin Roach story'. Stoke Newington police station has a notoriously poor reputation in relation to the policing of the Black community and the handling of legitimate grievances and protests in the Hackney area.... (Hall 1989: 13). He nationalises it by pointing out that the Policing 
in Hackney 'Report is well aware that this is not an isolated story. It could be repeated in any inner-city area with a significant Black population in Britain today' (Hall 1989: 13-14). Consequentially, his intervention makes a wider claim about police and legitimacy [even though he does not use that term here]. He underlines that no one in authority has any idea or explanation of how Colin Roach died. Policing in Hackney also cannot offer an explanation, but nor can it provide an alternative narrative because the official one is so implausible. Moreover, beyond the police, Hall suggests that this one death calls into question the inquest/coroner's role in the UK legal process because that also was unable to provide any satisfactory account or findings of facts. As before, in putting his finger on these issues Hall is highlighting concerns that were the subjects of regular protests in the 1970s and 80s - police accountability and the coroners' courts (Ryan 2013). Then, as now, the echoes around justice and accountability are clear, such as the shooting of Mark Duggan in Tottenham in 2011, or in relation to the deaths at Hillsborough in 1989 (Scraton 2016). These lend weight to Hall's 1999 comment on relations between the police and black communities: 'Very little seems to have changed' (Hall 1999: 188).

In these moves Hall articulates and, more importantly, dis-and re-articulates a series of relationships. At one level, in constructing Colin Roach as an everyman he shifts the gaze away from stereotyped black masculinity ('mad and bad'). By making an individual case an emblem about justice he re-sets or re-articulates the question as an innately political one about race, state and nation in quite blunt terms: 'The present Government seems to believe that the 'rule of law' (which obliges the state itself to be bound and constrained by the law) is the same as 'law and order' (which is nothing but a convenient political catch-phrase meaning that the police and the courts should support the state, whatever it does, and protect it against any inconvenience)'. In addition, he commented that inner-city areas like Hackney are 'places in which the state itself, and administrations and authorities of various kinds, constantly intervene, always in the interest of influencing what happens on the ground in the direction which suits them, but rarely in order to strengthen justice and equality for the ordinary citizens who live in these harassed communities' (Hall 1989: 16-17).

\section{Conclusion}


The two instances of Hall's public engagements show how he intervened in the politics of crime, policing and race by recontextualising and dis- and re-articulating a set of relations around them. It would be facile to see Hall's contextualising strategy as always seeking to widen the canvas, that is, as setting particular instances within a larger frame or conjuncture. His analysis was subtler than this. He simultaneously and strategically widened and sometimes narrowed the frame. Thus the death of Colin Roach is about the rule of law and police accountability, but it is also a local story about policing in Hackney. Hall does not simply blur the local into the national; he draws out specifics as well as generalities. In making both cases into narratives about race, state and nation - of Englishness or Britain - he centres race into the national story. While his frequent use of biographical and personal illustrations are less in evidence in the two examples discussed here, Hall interweaves the personal and the political in a 'post-colonial' outlook or perspective. This is well captured in this passage when he noted that: 'people like me who came to England in the 1950s have been there for centuries; symbolically we have been there for centuries. I was coming home at the bottom of the English cup of tea... There are thousands of others besides me that are you know, the cup of tea itself. Because they don't grow it in Lancashire, you know ... there is no English history without the other history' (Hall 1991:48-49). Although he did not spell it out as such, Hall's approach underscores that Colin Roach and Stephen Lawrence are also part of both 'the other story' and of English history, and they are essentially intertwined.

My claim is that Hall's strategising points the way to what anti-racism in criminology might entail or require. Race and culture are not 'add ons' but form the fabric in which crime and policing are to be thought about. However while race is central it is never 'just' race in a narrow sense. In engaging in a cultural politics of articulation, or more accurately of dis-and re-articulation, Hall offers clues on what an anti-racist criminology might do, without any noticeable concern as to whether he was 'in' criminology or not, or what its boundaries are. His work on public cases and contributing to inquiries could be part of the criminology 'from below' that Ryan (2013) invokes. Yet Hall's theorising of the concrete is not about 'above' or below', 'top down' or bottom up', 'national' or 'local'. Rather, he transcends and cuts across all of those and fuses them in a distinctive way. Nonetheless this does not mean that one can simply divine how to 'apply Stuart Hall'. Contextualizing is a concrete and 
radical tactic not a superficial exercise (Grossberg 2006). Alongside this attention to the concrete, Hall's use of concepts like conjuncture and articulation call for the analysis and linking of specificities into the appropriate and convincing frame, and to find ways to dis-and re-articulate connections between race, crime and policing.

\section{Acknowledgment}

Versions of this paper were presented at the Abo Akdademi, Finland and the University of Surrey. I thank the organisers and participants for their comments. I am grateful to Rod Earle, Alpa Parmar and Corretta Phillips for their advice and assistance.

\section{References}

Alexander, C (2009) Stuart Hall and 'race', Cultural Studies, 23:4, 457-482

Brooks, D (2003) Steve and me: my friendship with Stephen Lawrence and the search for justice, London: Abacus

Cashmore, E and McLaughlin, E (eds) (1992) Out of Order? Policing Black People, London: Routledge

Clarke, J (2015) Stuart Hall and the theory and practice of articulation. Discourse: Studies in the cultural politics of education, 36(2): 275-286.

Gilroy, P (1987) There ain't no black in the Union Jack: the cultural politics of race and nation, London: Routledge

Grossberg, L (2006) Does Cultural Studies Have Futures? Should It? Cultural Studies, 20(1): 1-32

Grossberg, L. (2007) Stuart Hall on race and racism: cultural studies and the practice of contextualism, in B.Meeks (ed) Culture, Politics, Race and Diaspora: The Thought of Stuart Hall, London: Lawrence \& Wishart.

Hall, S (1978) Racism and Reaction, in Five Views of Multi-Racial Britain London:

Commission for Racial Equality, pp. 23-35.

Hall, S (1980a) Race, Articulation, and Societies Structured in Dominance, in

Sociological Theories: Race and Colonialism, Paris: UNESCO, pp. 305-45.

Hall, S (1980b) Drifting into a Law and Order Society, London: Cobden Trust

Hall, S (1988) The Hard Road To Renewal: Thatcherism and the Crisis of the Left London: Verso

Hall, S (1989) Foreword, in Independent Committee of Inquiry, Policing in Hackney: 1945-1984 London: Karia Press, pp. 12-18.

Hall, S. (1991) Old and New Identities, Old and New Ethnicities, in A D. King (ed.)

Culture Globalization and the World System, London: Macmillan, pp. 41-68.

Hall, S (1997) The Spectacle of the Other, in S. Hall (ed.) Representation: Cultural

Representations and Signifying Practices, London: Sage, pp. 223-90.

Hall, S (1998) The Great Moving Nowhere Show, Marxism Today (special issue), 914. 
Hall, S (1999) From Scarman to Stephen Lawrence, History Workshop Journal, no. 48,187- 97

Hall, S., Critcher, C., Jefferson, T., Clarke, J. and Roberts, B., (1978) Policing the crisis: Mugging, the state and law and order. London: Macmillan (revised edition 2013)

Hall, S, McLaughlin, E and Lewis, G (1998) Racial Stereotyping in the Police:

Statement on Research on Stereotyping and Racial Attitudes, produced for Deighton Guedalla solicitors

Hall, S and Massey, D (2010) Interpreting the crisis, Soundings, Number 44: 57-71

Hall, S, Massey D and Rustin, M (2015) After Neoliberalism: the Kilburn Manifesto London: Lawrence and Wishart

Hillyard, P. (1985) Lessons from Ireland. In B. Fine and R. Millar (eds) Policing the miners' strike, London: Lawrence \& Wishart, pp. 177-187

Holohan, S (2005) The Search for Justice in a Media Age: Reading Stephen Lawrence and Louise Woodward. Aldershot: Ashgate

Independent Committee of Inquiry (1989) Policing in Hackney 1945-1984. London:

Karia Press

Jhally, S (2016) Stuart hall: the last interview, Cultural Studies, 30:2, 332-345

Keith, M (1993) Race, riots and policing: lore and disorder in a multi-racist society.

London: UCL Press

McLaughlin, E. (2008) Hitting the panic button:

policing/'mugging'/media/crisis. Crime, Media, Culture, 4(1), pp.145-154.

Macpherson, W (1999) The Stephen Lawrence Inquiry: London: TSO

Murji, K (2017) Racism, Policy and Politics, Bristol: Policy Press

Murji, K and G.Bhattcharayya (eds) (2014) Race critical race scholarship, London:

Routledge

Parmar, A. (2017) Intersectionality, British criminology and race: Are we there yet?

Theoretical Criminology, 21(1), pp.35-45.

Peplow, S. (2019) Race and riots in Thatcher's Britain, Manchester: Manchester

University Press

Phillips, C. and Webster, C. (eds) (2013) New directions in race, ethnicity and crime.

London: Routledge

Procter, J. (2004) Stuart Hall. London: Routledge.

Rojek, C (2003) Stuart Hall. Cambridge: Polity.

Rustin, M (2007) 'Working from the symptom': Stuart Hall's political writing, in

B.Meeks (ed) Culture, Politics, Race and Diaspora: The Thought of Stuart Hall,

London: Lawrence \& Wishart.

Ryan, M. (2013) Lobbying from below. London: Routledge

Scraton, P. (2016) Hillsborough-the truth. London: Random House.

Slack, J D (1996) The theory and method of articulation in cultural studies, in D.

Morley and K H Chen (eds) Stuart Hall: Critical Dialogues in Cultural Studies

London: Routledge, pp. 113-130

Webster, C (2009) Stuart Hall, in Hayward, K., Maruna, S. and Mooney, J. (eds) Fifty key thinkers in criminology. London: Routledge.

\section{Notes}

\footnotetext{
${ }^{1}$ Though it is also a problematic text in some ways, as McLaughlin (2008) and Jhally (2016) suggest in quite different ways.
} 
${ }^{2}$ The Commission for Racial Equality (CRE) was the public body tasked with addressing racial discrimination in the UK. It was disbanded in 2007 and replaced by the Equality and Human Rights Commission.

${ }^{3}$ An example of this is Hall's critique [see the subtitle to Hall (1989)] of left responses to 'the new right' which failed to grasp the range of articulations invoked in the building of common-sense and neoliberal hegemony

${ }^{4}$ Peplow (2019) locates this consistent refusal as part of the mindset of the Thatcher government in the 1980 s.

${ }^{5}$ National Council for Civil Liberties. This organization is now better known as Liberty

${ }_{7}^{6} \mathrm{He}$ provides his own account of events and the inquiry in Brooks (2003).

${ }^{7}$ Jane Deighton, solicitor for Duwayne Brooks. This quote is from an interview with the author in 2016. For more detail see Murji (2017).

${ }^{8} \mathrm{He}$ refers to this in a passing line in 1999 when he notes that race-related events were commonly 'followed by a campaign, unofficial inquiries (I sat on two), recriminations from the authorities, promises of reform' (Hall 1999: 188).

${ }^{9}$ Although in the latter case a man was convicted of the murder.

${ }^{10}$ As well as on Cashmore and McLaughlin (1992). 